\title{
DIAGNOSIS AND MANAGEMENT OF GASTROESOPHAGEAL REFLUX DISEASE
}

\author{
Diagnóstico e tratamento da doença do refluxo gastroesofágico
}

\author{
Maria Aparecida Coelho de Arruda HENRY
}

From the Department of Surgery and Orthopedy, School of Medicine, São Paulo State University (UNESP), Botucatu, SP, Brazil

HEADINGS - Gastroesophageal reflux. Diagnosis. Therapeutics. Fundoplication. Surgery.

\section{Correspondence:}

Maria Aparecida Coelho de Arruda Henry e-mail: rhenry@ibb.unesp.br

Financial source: none

Conflicts of interest: none

Received for publication: 06/12/2013 Accepted for publication: 08/05/2014

DESCRTORES - Refluxo Gastroesofágico. Diagnóstico. Terapêutica. Fundoplicatura. Cirurgia.
ABSTRACT - Introduction: Gastroesophageal reflux disease (GERD) is probably one of the most prevalent diseases in the world that also compromises the quality of life of the affected significantly. Its incidence in Brazil is $12 \%$, corresponding to 20 million individuals. Objective: To update the GERD management and the new trends on diagnosis and treatment, reviewing the international and Brazilian experience on it. Method: The literature review was based on papers published on Medline/Pubmed, SciELO, Lilacs, Embase and Cochrane crossing the following headings: gastroesophageal reflux disease, diagnosis, clinical treatment, surgery, fundoplication. Results: Various factors are involved on GERD physiopathology, the most important being the transient lower esophageal sphincter relaxation. Clinical manifestations are heartburn, regurgitation (typical symptoms), cough, chest pain, asthma, hoarseness and throat clearing (atypical symptoms), which may be followed or not by typical symptoms. GERD patients may present complications such as peptic stenosis, hemorrhage, and Barrett's esophagus, which is the most important predisposing factor to adenocarcinoma. The GERD diagnosis must be based on the anamnesis and the symptoms must be evaluated in terms of duration, intensity, frequency, triggering and relief factors, pattern of evolution and impact on the patient's quality of life. The diagnosis requires confirmation with different exams. The goal of the clinical treatment is to relieve the symptoms and surgical treatment is indicated for patients who require continued drug use, with intolerance to prolonged clinical treatment and with GERD complications. Conclusion: GERD is a major digestive health problem and affect $12 \%$ of Brazilian people. The anamnesis is fundamental for the diagnosis of GERD, with special analysis of the typical and atypical symptoms (duration, intensity, frequency, triggering and relief factors, evolution and impact on the life quality). High digestive endoscopy and esophageal pHmetry are the most sensitive diagnosctic methods. The clinical treatment is useful in controlling the symptoms; however, the great problem is keeping the patients asymptomatic over time. Surgical treatment is indicated for patients who required continued drug use, intolerant to the drugs and with complicated forms of GERD.
RESUMO - Introdução: A doença do refluxo gastroesofágico (DRGE) é, provavelmente, uma das doenças mais prevalentes no mundo que compromete significativamente a qualidade de vida. Sua incidência no Brasil é de 12\%, o que corresponde a 20 milhões de indivíduos. Objetivo: Atualizar o manuseio da DRGE e as novas tendências no diagnóstico e tratamento, revendo as experiências internacional e brasileira sobre o tema. Método: Foi realizada revisão da literatura baseada em artigos publicados no Medline/Pubmed, SciELO, Lilacs, Embase e Cochrane cruzando os seguintes descritores: doença do refluxo gastroesofágico, diagnóstico, tratamento clínico, cirurgia, fundoplicatura. Resultados: Vários fatores estão envolvidos na fisiopatologia da DRGE, sendo o mais importante o relaxamento transitório do esfíncter inferior do esôfago. As manifestações clínicas são azia, regurgitação (sintomas típicos), tosse, dor torácica, asma, rouquidão e pigarro (sintomas atípicos), que podem ser seguidos ou não de sintomas típicos. Pacientes com DRGE podem apresentar complicações como estenose péptica, hemorragia e esôfago de Barrett, que é o fator predisponente mais importante para adenocarcinoma. O diagnóstico deve ser baseado na anamnese e os sintomas devem ser avaliados em termos de duração, intensidade, frequência, fatores precipitantes e relevância, padrão de evolução e impacto na qualidade de vida do paciente. O diagnóstico exige confirmação com exames diferentes. $O$ objetivo do tratamento clínico é aliviar os sintomas e o tratamento cirúrgico é indicado para os que necessitam de uso contínuo de drogas, com intolerância ao tratamento clínico prolongado e com complicações. Conclusão: A anamnese é fundamental para o diagnóstico de DRGE, com análise especial dos sintomas típicos e atípicos. Endoscopia digestiva alta e pHmetria esofágica são os métodos diagnósticos mais sensíveis. O tratamento clínico é útil no controle dos sintomas; no entanto, o grande problema é manter os pacientes assintomáticos ao longo do tempo. $\mathrm{O}$ tratamento cirúrgico é indicado para pacientes que necessitaram o uso contínuo de drogas, intolerantes às drogas e com formas complicadas da DRGE.

INTRODUCTION

G astroesophageal reflux disease (GERD) is a major digestive health problem due to its ever high and increasing incidence and because it is the cause of serious complications. It is defined as a condition that involves gastric content reflux with ensuing symptoms or complications ${ }^{33}$. It is one of the most frequent causes of gastroenterological consultations in out-patients and compromises the quality of life of the patients significantly ${ }^{43}$.

The objective of this review was to update the GERD management and the new 
trends on diagnosis and treatment, reviewing the international and Brazilian experience on it.

\section{METHOD}

\section{Symptoms}

A population study was conducted in 22 cities from different regions of Brazil involving 13,959 adults older than 16 years of age. The participants replied a questionnaire on heartburn complaints and frequency. Heartburn occurrence over once a week was reported by $12 \%$ of the participants, which corresponds to 20 million Brazilians who are affected by GERD ${ }^{34}$.

In a similar study, Oliveira et al. (2005) ${ }^{40}$ surveyed 3,934 individuals from Pelotas, Rio Grande do Sul state regarding heartburn symptoms and/or bitter taste. They reported that $31.3 \%$ of the investigated population presented symptoms at least once a week. Association with women, aging and stress was reported in population studies ${ }^{6}$.

Similar and sometimes higher values have been reported in other Western countries. Lower incidence rates in Eastern countries (India - 7.5\%, Malaysia - 3.0\%, China $0.8 \%$ ) suggest that environment, alimentary habits and even race contribute with factors on GERD ${ }^{10}$.

The most relevant contributing factor to GERD is the transient lower esophageal sphincter relaxation. It may last from 5 to $35 \mathrm{~s}$ and is not related to swallowing; it occurs when the gastric fundus is distended by food or gas ${ }^{5,31}$.

In addition to transient lower esophageal sphincter relaxation, other factors participate in the physiology of GERD, such as lower esophageal sphincter hypotonia, alteration in the gastroesophageal anti-reflux barrier as a result of slipping hiatus hernia, inadequate esophageal peristalsis, lesion of the esophageal mucosa, obesity, pregnancy and the use of estrogens ${ }^{5,17,24}$

GERD patients, especially with chronic disease, may present complications such as Barrett's esophagus (BE), peptic stenosis, and hemorrhage. BE is a most relevant complication due to the susceptibility of evolution to adenocarcinoma. It involves the substitution of the esophageal squamous epithelium, usually in the distal portion of the esophagus, with glandular columnar epithelium with calciform cells and affects from 10-15\% of chronic GERD patients. Another major complication is peptic stenosis, more frequent in patients with severe esophagitis associated with dysphagia resulting in esophageal obstruction. Hemorrhage from esophageal ulcers is the least frequent complication.

\section{Diagnosis}

The main resource in GERD diagnosis is the clinical history. The anamnesis must identify the characteristic symptoms, their duration, intensity, frequency, triggering and relief factors, evolution over time and the impact on the quality of life ${ }^{33}$. Typical symptoms reported by most patients are heartburn and acid regurgitation. Heartburn is a retrosternal burning sensation that irradiates from the manubrium of the sternum to the base of the neck or throat. It generally occurs 30-60 min after eating, especially a large meal or a meal rich in fat or acid foods. It may be relieved by taking antacid or even water ${ }^{32}$. Acid regurgitation is the reflux of the acid content into the oral cavity.

If the patients present these symptoms at least twice a week in a period of four to eight weeks or more, GERD diagnosis must be considered. However, one must bear in mind that other diseases, such as peptic ulcer, gastritis and gastric cancer, have similar symptoms.

GERD may present other clinical manifestations as well. The most frequent atypical manifestations are non-coronary thorax pain, respiratory manifestations (cough and bronchial asthma), otorhinolaryngologic disorders (dysphonia, throat clearing and pharyngeal globus sensation), and oral disorders (dental erosion, aphtha and halitosis) 1,14,15,22,37 (Table 1).

TABLE 1 - Typical and atypical GERD manifestations

\begin{tabular}{|c|c|c|c|}
\hline \multirow{2}{*}{$\begin{array}{c}\text { Typical } \\
\text { manifestations }\end{array}$} & \multicolumn{3}{|c|}{ Atypical manifestations } \\
\hline & Pulmonary & $\begin{array}{l}\text { Othorhyno- } \\
\text { laringological }\end{array}$ & Orals \\
\hline $\begin{array}{l}\text { Heartburn } \\
\text { Acid } \\
\text { Regurgitation }\end{array}$ & $\begin{array}{c}\text { Chronic cough } \\
\text { Pharyngitis } \\
\text { Throat clearing } \\
\text { Pneumonia } \\
\text { Bronchiectasia } \\
\text { Asthma }\end{array}$ & $\begin{array}{c}\text { Hoarseness } \\
\text { Otitis } \\
\text { Sinusitis }\end{array}$ & $\begin{array}{c}\text { Dental erosion } \\
\text { Halitosis } \\
\text { Aphtha }\end{array}$ \\
\hline
\end{tabular}

Patients with atypical manifestations may not present the typical GERD symptoms. The screening criteria for the investigation of GERD in patients with chronic cough were not smoking patients and absence of environmental irritants, non-asthmatic, retronasal secretion, normal thorax and sinus radiographs ${ }^{1}$. Patients with otorhinolaryngological manifestations initially visited an area specialist and performing laryngoscopy, which may reveal GERD-specific lesions, such as edema, erythema, vocal cord nodules, granulomas ${ }^{22}$.

\section{Diagnosis methods}

More frequently the patients had a mean age of 54 years, presented heartburn and acid regurgitation and GERD test sensitivity of $67 \%$ and specificity of $77 \%^{33}$. Thus, the GERD diagnosis confirmation required further exams.

High digestive endoscopy

This is the exam of choice in the evaluation of patients with GERD symptoms and it is indicated in chronic cases in patients over 40 years old and with alarm symptoms, such as dysphagia, odynophagia, weight loss, digestive hemorrhage, nausea, vomits, and family history of cancer. It allows the diagnosis of other disorders as well, such as peptic ulcer, esophageal moniliasis, gastric cancer and eosinophilic esophagitis, which also present dyspepsia symptoms. It also allows the observation of erosions (limited dissolution of mucosa continuity with at least $3 \mathrm{~mm}$, fibrin deposition and neutrophilic epithelial permeation, which is characteristic of esophagitis), ulcers (dissolution of mucosa continuity reaching at least the mucosa muscle layer), Barrett's esophageal peptic stenosis ${ }^{5}$. Other lesions that do not allow GERD diagnosis due to their subjectivity may also be observed, such as edema, erythema and friability.

Various classifications have been proposed to characterize the intensity of reflux esophagitis. The most commonly used is the Los Angeles Classification (Table 2). It is worth pointing out that esophagitis is diagnosed in only $40 \%$ of GERD patients and that its severity does not correlate with the intensity of the symptoms ${ }^{20}$. Nasi et al. $(2001)^{38}$ disagree and reported to have observed intense heartburn in $37.5 \%$ of the patients with erosive esophagitis and in $10.3 \%$ of patients without erosion $(p<0.01)$.

\section{TABLE 2 - Los Angeles endoscopic classification}

\begin{tabular}{c|l}
$\begin{array}{c}\text { Degree } \\
\text { A }\end{array}$ & Finding \\
One or more erosions smaller than $5 \mathrm{~mm}$ \\
B & $\begin{array}{l}\text { One or more erosions greater than } 5 \mathrm{~mm} \text { in its greater } \\
\text { extension, non-continual between esophageal fold apices }\end{array}$ \\
C & $\begin{array}{l}\text { Contiguous (or convergent) erosions between at least } \\
\text { esophageal fold apices, commitment of less than } 75 \% \text { of } \\
\text { the esophagus }\end{array}$ \\
D & Erosion of at least $75 \%$ of the esophagus circumference
\end{tabular}


The complementation of the endoscopic exam with biopsy must not be a routine procedure and must be reserved for special situations, such as stenosis, ulcer and BE.

\section{Radiological examination of the esophagus}

This examination has low sensitivity and specificity in the diagnoses of GERD. It must be ordered when the patient reports dysphagia and/or odynophagia, since it allows the morphological evaluation of the esophagus and demonstrates the occurrence of stenosis and conditions that favor gastroesophageal reflux, such as slipping hiatus hernia and abnormal gastroesophageal angle ${ }^{37}$.

\section{Computerized esophageal manometry}

Esophageal manometry is not used for diagnosis purposes; however, it provides very useful information for the evaluation of the pressure tonus of the esophageal sphincters and the motor activity of the body of the esophagus. It has a predictive value in the assessment of the evolution of GERD. Thus, the diagnosis of severe lower esophageal sphincter hypotonia (lower than $10 \mathrm{~mm} \mathrm{Hg}$ ) indicates clinical maintenance treatment or even surgical fundoplication. Andreollo et al. (2010) observed its hypotonia in $29.5 \%$ of the patients submitted to laparoscopic fundoplication.

Other indications for esophageal manometry are: a) localization of the esophageal sphincters, essential information for the correct positioning of $\mathrm{pH}$-metry sensors; b) diagnosis of specific motor disorders, such as achalasia, collagen disease, aperistalsis and severe hypocontractility; c) motor activity analysis previous to fundoplication to ensure that the esophagus has conditions to adapt to a gastroesophageal anti-reflux valve ${ }^{19,37}$.

\section{Esophageal scintigraphy}

This exam exhibits the gastroesophageal reflux after the ingestion on technetium ${ }^{99}$-marked contrast. This is a noninvasive technique that can be used in the diagnosis of GERD in children. However, this exam is expensive and available in few advanced centers ${ }^{43}$.

\section{Prolonged esophageal $\mathrm{pH}$-metry}

This is a specific and sensitive method for the diagnosis of gastroesophageal reflux that has a high correlation with its symptoms (symptom index). In addition to the diagnosis and evaluation of the intensity of GERD, this exam characterizes its pattern, that is, if it is orthostatic, supine or bipositional ${ }^{26}$. This exam is recommended in the following situations: a) GERD diagnosis in normal upper endoscopy; b) characterization of the gastroesophageal reflux pattern; c) contribution of acid reflux to atypical GERD manifestations with examination with a catheter with at least two sensors is advisable - one positioned at the distal esophagus, and the second at the upper esophageal sphincter or above -, for the diagnosis of gastroesophageal and laryngopharyngeal reflux, respectively; d) study of symptom recurrence after surgery; e) evaluation of the efficacy of the clinical treatment ${ }^{37}$.

In patients with normal $\mathrm{pH}$ values and with response favorable to proton pump inhibition (PPI), the diagnosis of non-erosive reflux disease is advisable. Another relatively common situation is the patient who presents normal $\mathrm{pH}$ values, a negative symptom index, and is irresponsive to PPI, which is suggestive of functional heartburn diagnosis.

Wireless prolonged esophageal $\mathrm{pH}$-metry (Bravo capsule) This method has the advantages of providing a greater comfort to the patient, longer esophageal $\mathrm{pH}$ recording (up to $96 \mathrm{~h}$ ), and the added advantage of non-displacement of the catheter, which may occur in the conventional $\mathrm{pH}$ metry. A capsule temporarily fixed by suction onto the distal esophageal mucosa telemetrically transmits signals to a receptor attached to the patient's belt for computer analysis. It is spontaneously released and is eliminated through the digestive tract. The use of this method is rather limited in Brazil due to the high cost of the capsule ${ }^{43}$. After a comparative study of the conventional and the wireless esophageal $\mathrm{pH}$ metry methods, Azzar et al. (2012) $)^{21}$ concluded that both are able to diagnose pathological gastroesophageal reflux.

\section{Bernstein test}

This is a provocative test in which the esophageal mucosa is perfused with a diluted hydrochloric acid solution. The appearance of symptoms during perfusion is associated with sensitivity and specificity of around $80 \%$. However, the results are only qualitative and do not allow the quantification of gastroesophageal reflux. It has nearly ceased to be used after the development of 24-h esophageal $\mathrm{pH}$-metry ${ }^{10}$.

\section{Esophageal impedanciometry}

This is a new method that demonstrates the antegrade and retrograde movements of the refluxate. In association with $\mathrm{pH}$-metry (esophageal impedance-pH-metry), it also evaluates the physical (liquid, gaseous, mixed) and chemical (acid, non-acid, mildly acid) nature of the refluxate. Therefore, this exam provides the characterization of liquid, gaseous or mixed refluxate and whether it is acid or non-acid. In patients irresponsive to PPI, non-acid reflux diagnosis is indicative of surgical treatment, as the fundoplication surgery eliminates these two types of reflux ${ }^{37}$.

\section{Therapeutic testing}

In patients under 40 years old with typical GERD complaints and without alarm manifestations, PPI full doses may be administered for four weeks associated with behavioral measures (Table 3). The test is considered positive when the symptoms disappear, with a strong indication of GERD diagnosis 5 .

TABLE 3 - Behavioral measures proposed by the 3rd Brazilian GERD Consensus

\section{Elevation of the bed head $(15 \mathrm{~cm})$}

Moderation in the ingestion of the following foods (based on 2. symptom correlation): fatty foods, citrus, coffee, alcoholic and/ or carbonated beverages, mint, peppermint, tomato, chocolate Special care with "at risk" medicines: anticholinergics, theophylline, calcium-channel blockers, alendronate

4. Avoidance of lying down in the $2 \mathrm{~h}$ following meals

5. Avoidance of large meals

6. Quitting of smoking

7. Reduction of body weight, if overweight

\section{Treatment}

There are two therapeutic approaches to GERD, clinical and surgical, the choice of which depends on the patient's characteristics (age, treatment adherence, personal preference, existence of comorbidity) and on factors such as treatment response, existence of esophageal mucosa erosions, atypical symptoms and complications ${ }^{10}$.

\section{Clinical treatment}

The goal of the clinical treatment is symptom relief, healing the esophageal mucosa lesions and prevention of the development of complications. It is based on pharmacological and non-pharmacological measures.

\section{Non-pharmacological treatment}

The non-pharmacological treatment involves behavioral measures (Table 3). In the last years, these recommendations have been questioned by some authors based on their lack of scientific foundation in addition to their deleterious effects to the patients' quality of life ${ }^{30}$. Castro et al. $(2000)^{12}$ reported 
that these measures do not benefit the great majority of GERD patients. Nevertheless, these recommendations are time honored and considered useful.

In addition to the recommendations, the patients' diet must be personalized considering their complaints about each food. The measures also contribute to improve the doctor-patient rapport and increase treatment adherence ${ }^{20}$.

\section{Pharmacological treatment}

Various drugs may be used to treat GERD. Currently, PPI are the drugs of choice, inhibiting the production of acid by the stomach parietal cells, thus reducing the aggression of the esophagus by acid. Omeprazole is the most used PPI and is freely distributed by the Brazilian Health Ministry to the low-income population. Full PPI doses for 4-8 weeks are the initial treatment of choice. If the patient's symptoms do not disappear, the dose must be doubled, one before breakfast and another before dinner.

Erosive GERD responds satisfactorily to clinical treatment ${ }^{18,36}$. However, the symptoms reappear after the medication is stopped because the disease is chronic and requires continued PPI use. This is the maintenance treatment and the dose must be appropriate to keep the patient asymptomatic. This therapy is efficient in the long term and no dysplasia or neoplasia was observed by Klinkenberg-Knoll et al. (2000) ${ }^{25}$ after following up 230 GERD patients under PPI for 11 years. However, it is worth pointing out that this type of treatment requires great discipline due to the associated eating and living habit restrictions. Clinical practice shows that young patients, who fail to adhere to the treatment, may benefit from on-demand treatment, that is, irregular doses as required.

Histamine $\mathrm{H}_{2}$ receptor antagonists and prokinetic drugs are considered second-line drugs. They act by blocking histamine $\mathrm{H}_{2}$ receptors in parietal cells and reducing acid excretion. The most commonly used are ranitidine, famotidine, cimetidine and nizatidine.

Prokinectic drugs act by accelerating gastric emptying however, they do not act on transient lower esophageal sphincter relaxation. The most used are metoclopramide and domperidone. They must be prescribed when there is gastroparesis.

If the patient presents side effects to PPI or histamine $\mathrm{H}_{2}$ receptor antagonists, alginate and sucralphate antacids may be prescribed for temporary symptom relief.

Special attention must be paid to pregnant women due to the teratogenic effect of these drugs. The importance of behavioral measures must be highlighted and the use of systemic absorption drugs must be avoided. The use of antacids is recommended. If the symptoms persist, histamine $\mathrm{H}_{2}$ receptor antagonists may be prescribed. Among the systemic agents, only its use is safe during lactation, as most drugs are excreted in the milk ${ }^{5}$.

Regarding the role of PPI in the treatment of GERD, from 20 to $42 \%$ of the patients do not respond satisfactorily to it, a condition known as refractory GERD. According to Moraes Filho (2012) ${ }^{34}$, the main causes of refractory GERD are: functional heartburn, non-adherence to treatment, inadequate prescription, genotypic differences, non-acid gastroesophageal reflux, autoimmune diseases, eosinophilic esophagitis, and misdiagnosis. The author also proposes that GERD may be associated with visceral hypersensitivity, which interferes in the clinical picture and heightens the symptoms. This condition may be improved by the prescription of tricyclic antidepressants (amitriptyline) and inhibitors of serotonin reuptake (fluoxetine).

Recent studies have demonstrated that new drugs can be used in GERD patients refractory to PPI treatment. These drugs act by inhibiting transient lower esophageal sphincter relaxation. A promising drug for the treatment of non-acid or weakly acid reflux patients is gamma-aminobutyric acid type $B^{9}$.

\section{Surgical treatment}

Surgical treatment is indicated for patients who require continued drug use, intolerant to prolonged clinical treatment and with complicated forms of GERD. Herbella \& Patti (2010) ${ }^{24}$ proposed that the surgical treatment must also be indicated for women in the menopause and with osteoporosis, given the possible interference of PPI in calcium absorption. The major difficulty in the clinical treatment is not controlling the symptoms, but keeping the patients asymptomatic over time.

The surgical treatment consists in making an antigastroesophageal reflux valve using the gastric fundus (fundoplication), as proposed by Nissen (1956) ${ }^{39}$. It corrects an anatomic defect by reducing the slipping hiatal hernia observed in $89 \%$ of pathological GERD patients ${ }^{31}$. Furthermore, it restores LES competence, as demonstrated by experimental and clinical studies $23,24,28,41$.

There are three main surgical GERD procedures: total fundoplication (Nissen), in which the esophagus is completely surrounded $\left(360^{\circ}\right)$, partial fundoplication (Toupet), and mixed fundoplication, introduced by Brandalise \& Aranha (1996) ${ }^{8}$ (Figure 1).

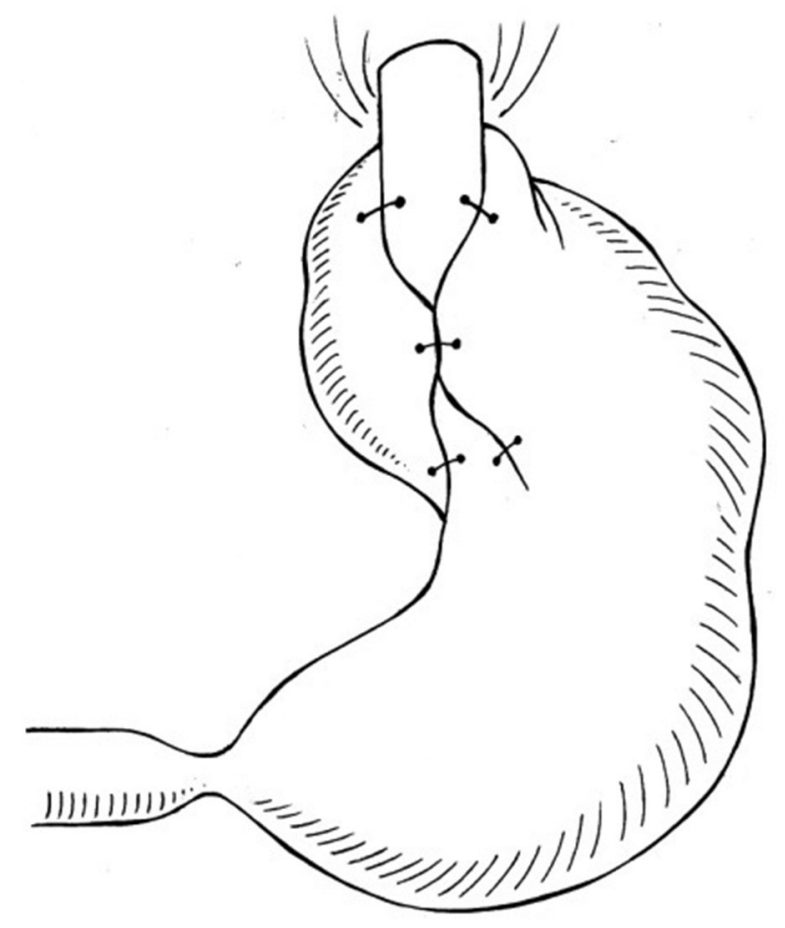

FIGURE 1 - Brandalise \& Aranha's fundoplication procedure ${ }^{8}$

The early 1990s saw a significant increase in the number of referrals to surgical GERD treatment coincident with the description of video-laparoscopic fundoplication by Dallemagne et al. (1991) $)^{36}$. This technique affords access to the abdominal cavity without the need of large incisions and allows performing the surgery with full reproduction successfully using the well-established laparotomy surgery, which was a great advance in surgery ${ }^{28}$. The advantages of video-laparoscopic fundoplication are many, among them the reduction of post-surgery pain, fast recovery, early hospital discharge, reintegration of daily activities and return to work in a short time, favorable aesthetic aspect, minimal change in life style stand out ${ }^{28}$. Additionally, the reduced incision size and minimal post-surgery pain allow early patient deambulation and fast recovery of diaphragm movement, minimizing the development of respiratory complications ${ }^{13}$. 
Excellent and good results have been achieved in 90-93\% of the patients submitted to this type of treatment ${ }^{11,13,19,24,28}$.

Esophagus or stomach perforation with ensuing death in most cases is considered the most important videolaparoscopic fundoplication complication. This complication occurs in a small number of patients (0.5-2\%) and decreases significantly with the surgeon's experience. Among the late complications, dysphagia occurs in $8 \%$ of the patients, mostly in those submitted to total fundoplication. The evolution is benign in most cases. Symptom persistence requires endoscopic dilation or even a new surgery, with resulting total remission. Andrade et al. (2012) ${ }^{2}$ analyzed the quality of life of 43 patients submitted to surgical GERD treatment and reported that $58.1 \%$ were very satisfied and $37.2 \%$ were satisfied with the result.

The definite referral to surgical GERD treatment hinges on GERD complications. Various factors must be analyzed before surgery referral to BE patients, the major ones being age, lesion size, existence and severity of dysplasia. For many years BE was thought not to relapse after clinical or surgical treatment; however, recent studies have demonstrated otherwise. Gurski et al. (2003) ${ }^{21}$ evaluated 91 BE patients who had clinical (14) and surgical (77) treatment and demonstrated that the lesions regressed in $36.4 \%$ of the surgically treated patients and in $7.1 \%$ of those treated with PPI. Regression occurred mostly in patients with short BE (less than $3 \mathrm{~cm}$ long). A similar result was observed by Carvalho et al. $(2011)^{11}$, with lesion regression in $63.8 \%$ of the cases and only one patient evolved to adenocarcinoma. Szachnowicz et al. $(2012)^{44}$ reported lesion regression in $8.9 \%$ of 221 surgically treated patients and progression to adenocarcinoma in three.

The analysis of these studies shows that surgical treatment is more efficient for metaplasia regression in short $\mathrm{BE}$; however, operated patients cannot be claimed to be free of malign degeneration and still require endoscopic followup, especially when the lesion is long (with $3 \mathrm{~cm}$ or more), since progression to cancer is more common in this group ${ }^{44}$.

A conservative treatment with full PPI doses twice a day with endoscopic follow-up is advisable in asymptomatic patients with short $B E$, particularly the elderly, when lesion dysplasia does not exist or is small. For patients with long $B E$, surgical treatment is preferable, even if they are asymptomatic, with total fundoplication, especially in young patients, who have a greater risk of malignant degeneration.

Transhiatal subtotal esophagectomy is reserved for BE patients who also present extensive dysplasia after 3-month PPI treatment after new biopsy and diagnosis confirmation by two pathologists.

Peptic stenosis is another GERD complication with low incidence after the introduction of PPI treatment. Fundoplication preceded by endoscopic dilation has had favorable results. Another uncommon complication is hemorrhage, which requires clinical treatment with double PPI doses for over eight weeks.

GERD associated with obesity is frequent as a result of the world obesity epidemics ${ }^{7}$. Fundoplication must not be used in this case because the relapse rates are significant $t^{42}$. The most adequate procedure and one which has given good results in the remission of GERD symptoms in patients with a body mass index higher than $35 \mathrm{~kg} / \mathrm{m}^{2}$ of body surface is to refer to bariatric surgery.

Referral of patients with extra-esophageal manifestations to surgery, mostly fundoplication for chronic GERD patients with respiratory complaints, is common. Lopes et al. (2013) ${ }^{27}$ achieved good results with fundoplication in asthma patients with significant improvement of quality of life. Otorhinolaryngological manifestations are relatively frequent, the most being hoarseness. These patients are usually voice professionals, such as teachers and religious and sales persons ${ }^{29}$. Clinical treatment with full PPI doses twice a day associated with weekly voice therapy sessions has given good results and surgery is rarely used ${ }^{45}$.

\section{CONCLUSIONS}

GERD is a major digestive health problem and affect $12 \%$ of Brazilian people. The anamnesis is fundamental for the diagnosis of GERD, with special analysis of the typical and atypical symptoms (duration, intensity, frequency, triggering and relief factors, evolution and impact on the life quality). High digestive endoscopy and esophageal pHmetry are the most sensitive diagnosctic methods. The clinical treatment is useful in controlling the symptoms; however, the great problem is keeping the patients asymptomatic over time. Surgical treatment is indicated for patients who required continued drug use, intolerant to the drugs and with complicated forms of GERD.

\section{REFERENCES}

1. Abrahão-Junior LJ, Lemme EMO. Manifestações extra-esofágicas da DRGE. J Bras Med. 2012; 100(5):17-21.

2. Andrade FJC, Almeida ER, Santos MTBR,Soares-Filho E, Lopes JB, Silva RCV. Qualidade de vida do paciente submetido à cirurgia videolaparoscópica para tratamento para doença do refluxo gastroesofágico. ABCD Arq Bras Cir Dig. 2012; 25(3):154-160.

3. Andreollo NA, Lopes LR, Coelho-Neto JS. Doença do refluxo gastroesofágico: qual a eficácia dos exames no diagnóstico? Arq Bras Cir Dig. 2010; 23(1):6-10.

4. Azzam RS, Sallum RAA, Brandão JF, Navarro-Rodrigues T, Nasi A. Comparative study of two modes of gastroesophageal relux measuring: conventional esophageal monitoring and wireless $\mathrm{pH}$ monitoring. Arq Gastroenterol. 2012; 49(2):107-112.

5. Barczinski T, Moraes-Filho JPP. Doença do refluxo gastroesofágico na mulher. Rev Bras Med. 2006; 63(12):160-168.

6. Barros GSS. Doença do refluxo gastroesofágico - prevalência, fatores de risco e desafios. Arq Gastroenterol. 2005; 42(2):71-72.

7. Biccas BN, Lemme EMO, Abrahão Jr LJ, Aguero GC, Alavarez A Schechter RB. Maior prevalência de obesidade na doença do refluxo gastroesofágico erosiva. Arq Gastroenterol. 2009; 46:15-19.

8. Brandalise NA, Aranha NC. Doença do refluxo gastroesofágico: técnica operatória. In: Marchesini JB, Malafaia O. Doença do refluxo gastroesofágico. São Paulo, Atheneu, 1996, p.171-190.

9. Calado AF, Fernandes e Silva C, Menezes AC, Araujo-Filho I, Medeiros AC. Surgical treatment for gastroesophageal reflux disease. J Surg CI Res. 2013; 4(1):19-25.

10. Camacho-Lobato L. Doença do refluxo gastroesofágico. RBM Rev Bras Med. 2001; 58(8):550-561

11. Carvalho GL, Lira LHL, Chaves EFC, Silva JSN, Rocha RG, Brandt CT. Laparoscopic anti-reflux surgery promotes regression or disappearance of Barrett's esophagus, but does not eliminate the risk of esophageal adenocarcinoma. Bras J Video Sur. 2011; 4(1):15-20.

12. Castro LP, Brito EM, Coelho LGV. Doença do refluxo gastroesofágico. Rev Bras Med. 2000; 57(11):1214-1232.

13. Coelho JCV, Wiederkehr JC, Campos ACL, Andrigueto PC, Pinho $\mathrm{RV}$, Bonin EA. Complicações do tratamento laparoscópico da doença do refluxo gastroesofágico. Experiência de 600 casos. Rev Col Bras Cir. 2000: 26(4):237-242

14. Correa MCCSF, Lerco MM, Cunha MLRS, Henry MACA. Salivary parameters and teeth erosions in patients with gastroesophageal reflux disease. Arq Gastroenterol. 2012; 49(3):214-218.

15. Correa MCCSF, Lerco MM, Henry MACA. Estudo das alterações na cavidade oral em pacientes com doença do refluxo gastroesofágico. Arq Gastroenterol. 2008; 45(2):132-136.

16. Dallemagne B, Weerts JM, Jehaes C. Laparoscopic Nissen fundoplication: a preliminary report. Surg Lapar Endosc. 1991; 1:138-139.

17. El-Serag HB, Graham DY, Satia JÁ, Rabenek L. Obesity is na independent risk factor for GERD symptoms and erosive esophagitis. Am J Gastroenterol. 2005; 100:1243-1250.

18. Freitas JA, Lima LMP, Ranieri, JL,Olivieri JC, Fragoso HJ, Chinzon D. Avaliação da eficácia - segurança e tolerabilidade de rabeprazol no tratamento de doenças ácido-pépticas. Arq Gastroenterol. 2002; 39(1):60-65. 
19. Funes HLX, Anai GK, Santos MCL, Leite APM, Salvador FC. Videolaparoscopia no tratamento da doença do refluxo gastroesofágico. Rev Col Bras Cir. 2000; 27(5):312-315.

20. Galvão-Alves J. Doença do refluxo gastroesofágico. J Bras Med. 2012; 100(3):67-71.

21. Gurski RG, Peters JH, Hagen JÁ, De Meester SR, Bremmer CG, Chandrasoma PT, De Meester TR. Barrett's esophagus can and does regress after antireflux surgery: a study of prevalence and predictive features. J Am Coll Surg. 2003; 169(5):706-713.

22. Henry MACA, Martins RHG, Lerco MM, Carvalho LR, LamônicaGracia VC. Gastroesophageal reflux disease and vocal disturbances. Arq Gastroenterol. 2011; 48(2):98-103.

23. Henry MACA, Motta DCP, Silva RA. Avaliação manométrica do esôfago distal de coelhos submetidos a fundoplicatura total laparotômica e laparoscópica. Arq Gastroenterol. 2002; 39(2):106-110.

24. Herbella FA, Patti MG. Gastroesophageal reflux disease: From pathophysiology to treatment. World J Gastroenterol. 2010; 16(30):3745-3749.

25. Klinkenberg-Knol EC, Nelio F, Dent J, Snel P, Mitchell B, Prichard P, Lloyd D, Havre N, Frame MH, Roman J, Walan A; Long-Term Study Group. Long-term omeprazole treatment in resistant gastroesophageal reflux disease: efficacy, safety, and influence on gastric mucosa. Gastroenterology 2000: 118:1-9.

26. Lemme EMO, Almeida SM, Firman CG, Pantoja JP, Nascimento FAP. pHmetria esofagiana prolongada - avaliação de 170 exames. Arq Gastroenterol. 1997; 34:71-77.

27. Lopes LR, Bertanha L, Silva PR, Vedan AB, Carvalheiro AP, CoelhoNeto JS, Tercioti Junior $V$, Andreollo NA. Avaliação cirúrgica laparoscópica anti-refluxo nos portadores de sintomas extra esofágicos relacionados à asma na DRGE. Arq Gastroenterol. 2013; 50 - Suplemento. p.44.

28. Lopes LR, Brandalise NA, Andreollo NA, Leonardi LS. Tratamento cirúrgico videolaparascópica da doença do refluxo gastroesofágico: técnica de Nissen modificada - resultados clínicos e funcionais. Rev Ass Med Brasil. 2001; 47(2):141-148.

29. Martins RHG, Branco A, Tavares ELM, Iyomassa RM, Carvalho LR, Henry MACA. Laryngeal and voice disorders in patients with gastroesophageal symptoms. Correlation with $\mathrm{pH}-$ monitoring. Acta Cir Bras. 2012; 27(11):821-828.

30. Meining A, Classen $M$. The role of diet and lifestyle measures in the pathogenesis and treatment of gastroesophageal reflux disease. Amer J Gastroenterol. 2000; 95(10):2692-2697.

31. Mittal RK, Holloway RH, Penagini R, Blackshaw LA, Dent J. Transient lower esophageal sphincter relaxation. Gastroenteroloy. 1995; 109(2):601-610.

32. Moraes-Filho JPP, Cecconello I, Gama-Rodrigues JG, Castro LP, Henry MA, Meneghelli UG, Quigley E and the Brazilian Gerd Consensus Group. Brazilian Consensus on gastroesophageal reflux disease: proposals of assessment, classification and management. Amer J Gastroeneterol. 2002; 97(2):241-248.
33. Moraes-Filho JPP, Navarro-Rodrigues T, Barbuti R, Eisig J, Chinzon D, Bernardo W and the Brazilian Gerd Consensus Group. Guidelines for the diagnosis and management of GERD : An evident-based consensus. Arq Gastroenterol. 2010; 47:99-115.

34. Moraes-Filho JPP. Doença do refluxo gastroesofágico de difícil tratamento. RBM Rev Bras Med. 2012; 69(12):41-46.

35. Moraes-Filho JPP. Doença do refluxo gastroesofágico. RBM Rev Bras Med. 2007; 64(8):348-354.

36. Moretzsohn LD, Brito EM, Reis MSF, Coelho GV, Castro LP. Assessment of effectiveness of different dosage regimens of pantoprazole in controlling symptoms and healing esophageal lesions of patients with mild erosive esophagitis. Arq Gastroenterol. 2002; 39(2):123-125.

37. Nasi A, Moraes-Filho JPP, Cecconello I. Doença do refluxo gastroesofágico: revisão ampliada. Arq Gastroenterol. 2006; 43(4):334-340.

38. Nasi A, Moraes-Filho JPP, Zilberstein B, Cecconelo I, GamaRodrigues J. Doença do refluxo gastroesofágico: comparação entre as formas com e sem esofagite, em relação aos dados demográficos e às manifestações sintomáticas. Arq Gastroenterol. 2001; 38(2):109-115.

39. Nissen R. Gastropexy as the alone procedure in the surgical repair of hiatus hérnia. Am J Surg. 1956; 92:389-392.

40. Oliveira SS, Santos IS, Silva JFP. Prevalência e fatores associados a doença do refluxo gastroesofágico. Arq Gastroenterol. 2005; 42(2):116-121.

41. Oliveira WK, Henry MACA, Lerco MM. Avaliação manométrica do esfíncter inferior do esôfago de coelhos submetidos a fundoplicatura total e parcial. Acta Cir Bras. 2004; 19(5):555-564.

42. Perez AR, Moncure AC, Rattner DW. Obesity adversely affects the outcome of antireflux operations. Surg Endosc. 2001; 15:986-989.

43. Sarvat MA, Domingues GRS. Repercussões laríngeas do refluxo gastroesofagofaringea. In: Caldas Neto S, Mello Jr JF, Martins RHG, Costa SS. Tratado de Otorrinolaringologia e Cirurgia Cervico Facial. Gen Roca Grupo Editorial Nacional: 2011, p 401-411.

44. Szachnowicz S, Seguro F, Sallum RAA, Nasi A, Moura EHG, Rocha J, Cecconello I. Late endoscopic surveillance in Barrett's esophagus submitted to fundoplication. Is it worthwhile? Diseases of Esophagus. 2012; 25 Supplement. P.64A.

45. Vashani K, Murugesh M, Hattiangadi G, Gore G, Keer V, Ramesh VS, Sandur V, Bhatia SJ. Effectiveness of voice therapy in reflux related with voice disorders. Diseases of Esophagus. 2010; 23:27-32. 